doi: 10.19090/i.2016.27.33-44

UDC: 730(3):069(569.44)

ORIGINAL SCIENTIFIC PAPER

Received: 30 May 2016

Accepted: 9 October 2016

\title{
IDIT SAGIV
}

Tel-Aviv University, Department of Art History

iditsagh@gmail.com

\section{THE IMAGE OF THE RIDER ON GRECO-ROMAN ENGRAVED GEMS FROM THE ISRAEL MUSEUM (JERUSALEM)}

\begin{abstract}
This paper explores the interpretations and context of equestrian Greco-Roman engraved gems kept at the Israel Museum in Jerusalem which had never been published prior to this study. It was written on the basis of a study which included photography, description, technical aspects, iconographic and stylistic analysis and, finally, dating the gems. In order to achieve this, they were compared to other known ones that had already been published.

The results indicate that horsemen frequently appear as subjects on intaglios. The Roman engraved gems drew their inspiration from established Greek rider imagery. Under the Roman Empire, the rider image became the preserve of that new divine figure, the emperor. The Imperial rider combined the attributes of a Bellerophon or the Dioscuri of the Classical period and an Alexander of the Hellenistic. Also, Gauls are fairly common in art and there are quite a number of Celtic/Gaulish horsemen on gems. Presumably, people wore such gems as a reminder of the iconic defeat of the Northern barbarians by the Attalids and more recent Roman triumphs. In addition, there are several examples of gems, on which appears a rider beneath whose horse a lion or another animal is lying. It is likely that this rider was perceived by the gem engraver and owner as some god or hero. Since these depictions of cavalry on gems are similar to the "Heros Equitans" image, possibly they were inspired by it and so were the depictions of the emperors.

Thus it is concluded that applying representations of riders on engraved gems demonstrates the possible wish of affluent, albeit ordinary people to resemble the ruling class as well as heroes through the purchase and use of these gems which also bear additional meanings of bravery and immortality.

Keywords: Engraved gems, intaglios, horsemen, cavalry, Heros Equitans, Bellerophon, Dioscuri, Imperial rider.
\end{abstract}

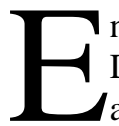
ngraved gems are precious or semi-precious stones featuring images on them. During the Greek and Roman periods they were used as seals, jewellery, and amulets. The various images carved on the gems represented gods, mythological themes, famous sculptures, astrological signs, and portraits. Many of the images are no longer familiar to us and research based on ancient literary sources is required in order to interpret their meanings. In their own time the depictions on the gems were both meaningful and also often symbolic. The primary function of engraved gems (intaglios) lay in their use 
to create an icon in a relief on clay or wax, which could be identified and whose role was to validate the act of signing. Such gems were highly appreciated in ancient times in general and in the Greco-Roman world in particular.

The great importance attributed to these gems is also reflected in the ancient literature. A seal was considered as a powerful metaphor of an individual and that individual's relationship with the surrounding world. Indeed, the seal imprint became such a powerful image that the term tupôsis (toposis) (the action of stamping the seal on wax) was used as a philosophical metaphor by Plato and later on in the Stoic writings in order to explain the nature of knowledge and the relationship between sensory perception and the soul. ${ }^{1}$ There was a parallel between the seal and its owner, with the image carved on the gem perceived as a specific identity marker and proclaiming an individual's continued presence even during their physical absence. ${ }^{2}$

The horseman was one of the most common images in Roman imperial iconography. Rider figures appear in sculpture in the round, in relief, and in painting and the minor arts, including on engraved gems. Five engraved gemstones in the collection of Classical Archaeology of the Israel Museum, Jerusalem, depict riders. The first one is a carnelian intaglio (16 x $12 \mathrm{~mm}$ ) set in an original gold frame, ${ }^{3}$ showing a horseman on a galloping horse and holding a spear in his right hand (Fig. 1). ${ }^{4}$ Part of the H. Stern Collection, it has not been published prior to this study.



Fig. 1 - Rider on a galloping horse, Carnelian, 16 x $12 \mathrm{~mm}, 1^{\text {st }}-2^{\text {nd }} \mathrm{CE}$, Israel Museum, inv. no. 76.42.2430.

\footnotetext{
${ }^{1}$ Plato, Theaetetus 191D- E, 193C, 194C, D; Diogenes Laertius, Lives of Eminent Philosohers (Life of Zeno) 7.177, 7.45-46, 7.50

${ }^{2}$ Platt 2006: $240-241$

${ }^{3}$ IMJ (Israel Museum, Jerusalem), inv. no. 76.42.2430. Sahara was one of two main sources of carnelian for the Roman world , the other being Northern India (Gliozzo et al. 2014: 218-241; Mattingly 2003; 2010; 2013).

${ }^{4}$ For the theme, see for example Sena Chiesa 1966: no. 926.
} 
The second one is a carnelian intaglio $(15 \times 12 \times 4 \mathrm{~mm}),{ }^{5}$ bearing a representation of a rider on a galloping horse facing a tree and holding a spear in his right hand, with an animal apparently being trampled beneath them (Fig. 2). Part of the A. Dorin Bequest, it too has not been published prior to this study.

The dating of these eclectic gems from the Israel Museum is extremely difficult, since their archaeological context is unknown. The sorting method developed by Marianne Maaskant-Kleibrink, ${ }^{6}$ who dealt with a similar collection, has therefore been very useful in dating the gems for the present study. Maaskant-Kleibrink sorted the gems according to style and engraving technique rather than workshop, since it was clear that they had been executed in different provinces. In addition, the material and the shape of the stones themselves have helped in establishing the correct date, or at least an approximate one, since different materials were typical of different periods. These features were highly dependent on changes in "fashion" and related to the different shapes for finger-rings. ${ }^{7}$ A close look at the carving technique of these two gems indicates they were modeled with a rounded drill. The hair on the figures' heads resembles a hat tightly fitted to the head and their legs are pointed and lumpy. These details place the Israel Museum intaglios (Figs. 1 and 2) in the "Imperial Cap-with-Rim Style", as defined by M. Maaskant-Kleibrink, and date to the end of the $1^{\text {st }}$ century CE- $2^{\text {nd }}$ century CE. ${ }^{8}$

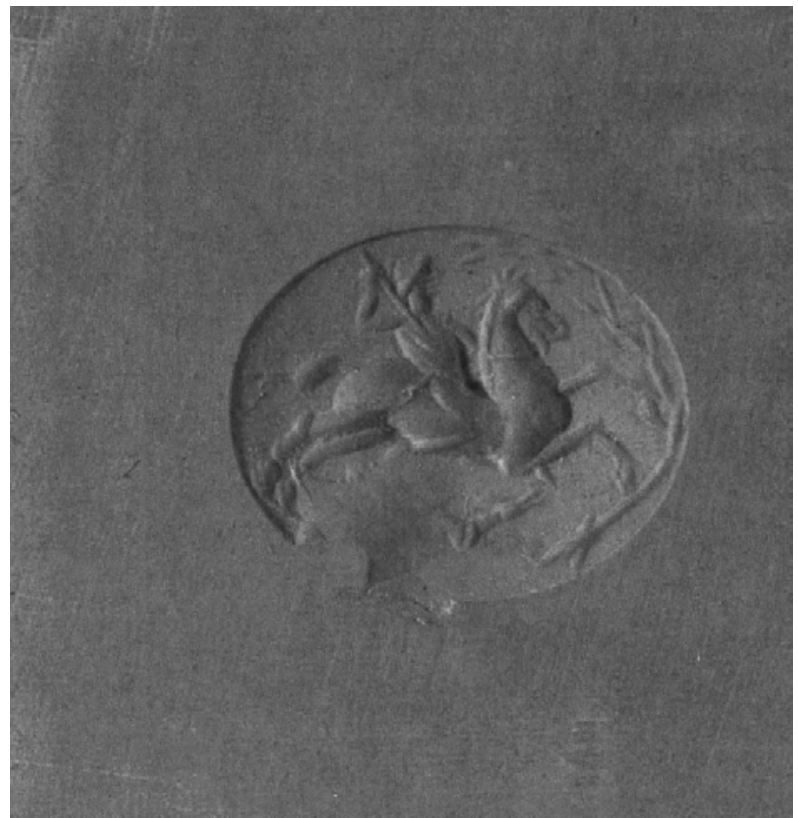

Fig. 2 - Horseman trampling an animal?, Carnelian, $15 \times 12 \times 4 \mathrm{~mm}, 1^{\text {st }}-2^{\text {nd }}$ century CE, Israel Museum, inv. no. 70.62.372.

\footnotetext{
${ }^{5}$ IMJ 70.62.372.

${ }^{6}$ Maaskant-Kleibrink 1978.

${ }^{7}$ Maaskant-Kleibrink 1978: 59-61.

${ }^{8}$ Maaskant-Kleibrink 1978: 302.
} 
These visual depictions of horsemen drew basically upon Greek imagery. In Greek art the development of the rider figure depended not on a divine iconography but on the human and heroic. In Greek classical times the horse was primarily a status symbol of kings and members of the aristocracy and it was used in battle, chariot races, ceremonial processions and also while hunting. ${ }^{9}$ Although the cavalry had no significant role in warfare, they had an important place in society, politics and the economy. The cavalry belonged to a class characterized by criteria of wealth, responsibility and additional rights beyond those granted to poorer citizens. ${ }^{10}$ Greek gods were described as riding in a chariot and not mounted on a horse. Gods depicted as riders were very rare. The Dioscuri too were usually depicted standing by their horses rather than mounted on them. The Greek god who was most frequently associated with horses was Poseidon, who even had equine offspring like Pegasus and Areion. In Boeotia and sometimes in Corinth Poseidon was worshiped as Poseidon Hippios and some of the votive tablets showed him as a rider. Most frequently, however, Poseidon was depicted riding a hippocampus. Other gods too were associated with horses. Athena and Demeter were both worshiped as Hippia but none of them have contributed to the iconography of the horseman. Cavalry figures began to appear on vases from mid $8^{\text {th }}$ century BCE. ${ }^{11}$ During the Archaic period riders began to feature on funerary monuments ${ }^{12}$ although fighting horsemen started to be seen on burial reliefs only during the $5^{\text {th }}$ century BCE. ${ }^{13}$ The rider motif, echoing mounted mythological heroes like Bellerophon, probably served to commemorate cavalrymen who had died in battle while also symbolizing their bravery and courage.

The Hellenistic period saw a new approach, influenced by Alexander the Great, and the art and iconography that were developed for him appear to have altered and raised the status of the rider. These were the first monuments to have as their subject a living and identifiable individual as opposed to a generalized ideal. ${ }^{14}$ With Alexander too, the distinction between gods and humans began to be blurred. Alexander's successors imitated him, as can be seen from the fragments of an equestrian statue of Demetrios Poliorketes, a life-size, or slightly over life-size, gilded equestrian statue. ${ }^{15}$

The third carnelian intaglio (16 x $12 \mathrm{~mm}$ ) from the Israel Museum (Fig. 3), ${ }^{16}$ depicting a rider with his chlamys fluttering behind him during the gallop, ${ }^{17}$ dates to $240-228$ BCE, according to its resemblance to a Vlasto coin (no. 943) from Tarentum. Hellenistic kings were often depicted on coins wearing this type of helmet, to which was added a crest feathers, in a similar way to the helmet depicted on the Israel Museum gem. ${ }^{18}$

\footnotetext{
${ }^{9}$ Richter 1930: p. 14.

${ }^{10}$ Harris 1972: 152-153.

${ }^{11}$ Anderson 1961: 10.

${ }^{12}$ Kurtz and Boardman 1971: 86, 221, pl. 50, fig. 15.

${ }^{13}$ Woysch-Meautis 1982: 25.

${ }^{14}$ Mackintosh 1995: 3-4.

${ }^{15}$ Houser 1982: 230.

${ }^{16}$ IMJ 76.42.2429.

${ }^{17}$ For the type, see Pannuti 1983: p. 108, no. 161; Maaskant-Kleibrink 1978: no. 402; Henig and Whiting 1987: no. 284.

${ }^{18}$ Snodgrass 1967: fig. 59; The type of helmet which appears on the gemstone from the Israel Museum is identified as a Boeotic one, which became widely used from the late $3^{\text {rd }}$ century BCE. Xenophon recommends this type of
} 


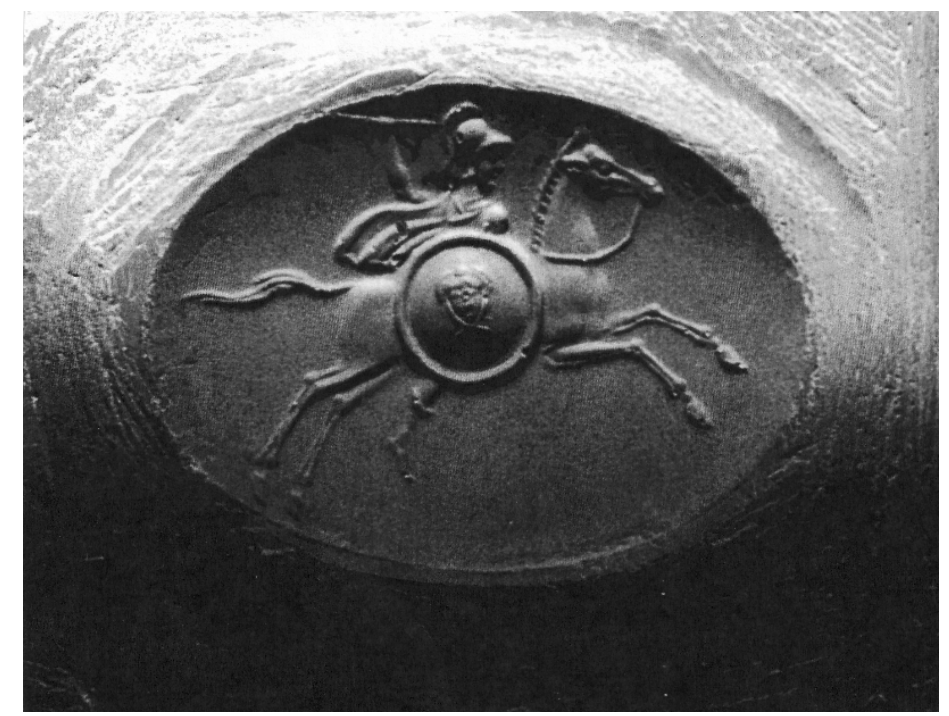

Fig. 3 - Rider with a spear on a horse, Carnelian, 10x14 mm, c. 240 BCE, Israel Museum, inv. no. 76.42.2429.

The imperial rider combined the attributes of a Bellerophon or the Dioscuri of the Classical period and an Alexander of the Hellenistic one. ${ }^{19}$ The mythological heroes like Bellerophon continued too to be represented, probably bearing the same meanings of immortality and bravery as in the earlier periods, as on the fourth engraved gem from the Jerusalem museum, dating to the $1^{\text {st }}$ century BCE $-1^{\text {st }}$ century CE, an amethyst intaglio (17 $\mathrm{x} 14 \mathrm{~mm}),{ }^{20}$ which depicts Bellerophon riding Pegasus, ready to kill the Chimera with his spear (Fig. 4). ${ }^{21}$ Part of the H. Stern Collection, it has not been published prior to this study. ${ }^{22}$ During the Roman Empire, the emperor, who was the new divine figure, adopted the habit of commissioning colossal rider statues. For example, Octavian was represented in sculpture at the beginning of his career as a rider astride a horse to generate public recognition for his services to the state and abilities as a military commander. The first of these statues was dedicated to him by the Senate and the Roman people in 43 BCE, when he was only 19 years old. The statue stood in the most visible place in Rome, suggesting that Caesar's successor would have great political power. This statue of Octavian is also depicted on

\footnotetext{
helmet for the cavalry as it causes minimum disturbance to the sight and hearing of its wearer (Xenophon, De re equestri xii.3; Waurick 1988: 159-163).

${ }^{19}$ Mackintosh 1995: 5.

${ }^{20}$ IMJ 76.42.2425. For the type, see Walters 1926: pls. xxiv: 1912, xxxii: 3181.

${ }^{21}$ Scenes of killing the Chimera, depicted on engraved gems, recall later scenes of killing dragons by Christian saints. This similarity is not coincidental. In the $4^{\text {th }}$ century CE, when Christianity had already gained influence in the Roman world, this was one of the pagan scenes that was adopted by Christians and given a new interpretation. Bellerophon was interpreted as a symbol of Christ and the Chimera as a symbol of evil. An example of this can be seen in a gold ring from Havering, Essex, dating to the $4^{\text {th }}$ century CE and bearing a depiction of Bellerophon killing the Chimera (Johns 2006: 173).

${ }^{22}$ For the theme, but with the Chimera, see for example Adams 2011: 11, pl. 3.
} 
coins. ${ }^{23}$ Before him, Sulla, Pompey the Great, and Julius Caesar had also been presented in this way as horsemen, and the placement of Octavian's sculpture was intended to exceed them in its shared honors. Later on, Octavian was displayed on sculptures in a similar way to that of the Dioscuri - as an omnipotent rescuer and savior. ${ }^{24}$

In similar fashion, the colossal equestrian statue of Domitian, erected in the Forum Romanum in $91 \mathrm{CE}$, was the subject of a poem by Statius extolling its virtue as the visualization of imperial invincibility. ${ }^{25}$ Originally a portrait of Domitian, the head was replaced later by that of Nerva. It was dedicated at the shrine of the Augustales, the priests of the imperial cult. The Domitian cuirass with Flavian symbols was left in place. It is the only galloping equestrian bronze statue that is known to have survived.

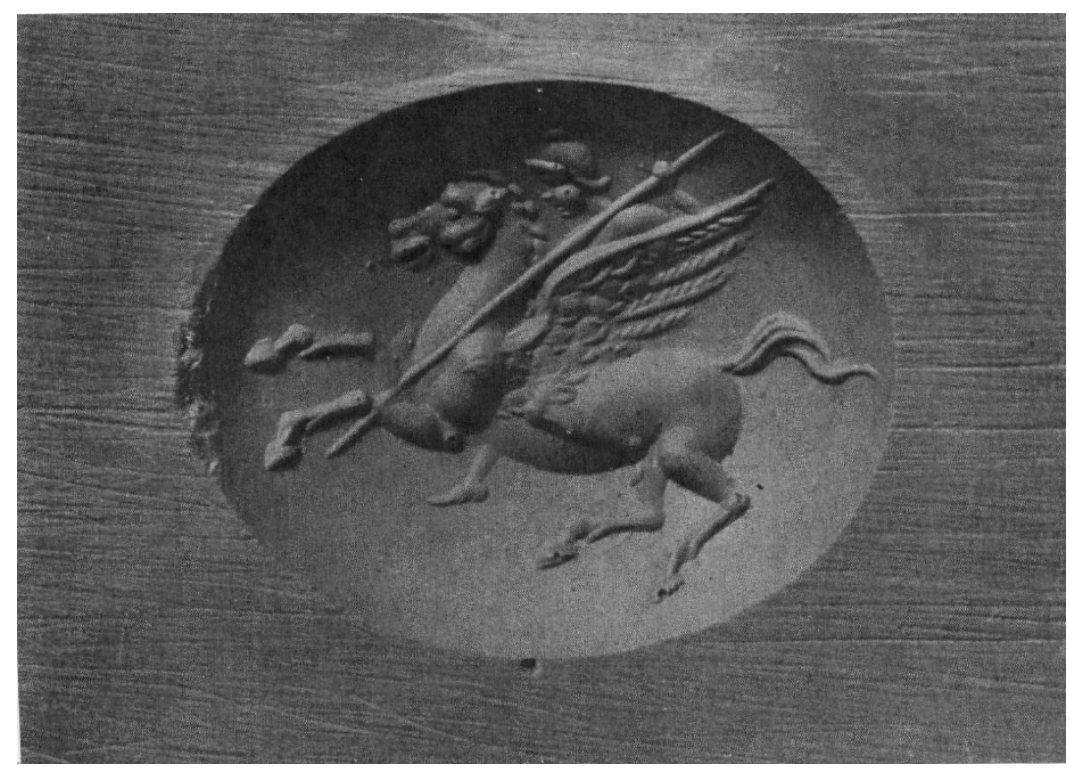

Fig. 4 - Bellerophon riding Pegasus, Amethyst, 17 x 14 x 5 mm, $1^{\text {st }}$ century BCE, Israel Museum, inv. no. 76.42.2425.

The spears which the riders are holding on gems from the Israel Museum enable their identification as warriors or heroes. The depictions of cavalrymen holding spears, unconnected with the image of any god, are known from sarcophagi, gravestones, monuments, and imperial gems. ${ }^{26}$ In most cases those riders are depicted galloping during the battle. ${ }^{27}$ There are also several examples of gems featuring a rider beneath whose horse

\footnotetext{
${ }^{23}$ Zanker 1988: fig. 29a.

24 Zanker 1988: 37-39, fig. 30.

25 cf. Hannestad 1986: 139.

${ }^{26}$ Hamburger 1968: no. 145; Maaskant-Kleibrink 1978: no. 993.

${ }^{27}$ Henig 1999: 156, fig. 2.
} 
is a kneeling or lying captive, such as on a gem from the Munich Museum. ${ }^{28}$ In other cases the depiction of a rider on a horse indicates a hunter setting out for the chase. Those depictions are common on Roman sarcophagi and no less so on gems. The second carnelian gem from the Israel Museum (Fig. 2) appears to be of this type, but since it is somewhat damaged it is difficult to discern what is depicted beneath the horse. This is probably a riderhunter with his prey, similar to the depiction on a gem from Dalmatia ${ }^{29}$ and another one from Berlin, ${ }^{30}$ on which the rider is depicted killing a lion. ${ }^{31}$ Another example is that of a gem from the Royal Coin Cabinet, the Hague (now in the Rijkmuseum van Outheden in Leiden), ${ }^{32}$ with a helmeted warrior astride a horse and galloping to the right, while attacking a lion with a spear held in his right hand. Generally, when regarding equestrian gems, the possibilities of interpretation might also include the presence of a wreath, which would indicate triumph in a horse-race, while wings might identify the figure as Eros. On a gem from Bath, England, late $1^{\text {st }}$ century CE, a rider on a horse waving a victory wreath is depicted and it is likely that this rider is a horse-race winner. ${ }^{33}$ A gem made of red jasper from the J. Paul Getty museum in Malibu, California features a rider on a horse. This horseman was identified by Jeffery Spier as Eros based on identifying the object fluttering behind this mythological figure as his wings. ${ }^{34}$

Henig engaged with the question of the meaning of the motif of the rider when he published a gem discovered at Aldborough, England, dated by him to the $1^{\text {st }}$ century or early $2^{\text {nd }}$ century CE. The gem depicts a soldier riding a horse, holding a spear and with two javelins behind him. It is easy to interpret this horseman as an auxiliary of the Roman army, mainly because the site at which the gem was discovered was once a Roman fortress. However, it is unclear what the protective or spiritual role of such a self portrait might be. Henig assumed that the rider was perceived by the gem engraver and owner as a god or hero, ${ }^{35}$ while Dimitrova too has argued that the horseman presents iconographical convention for a god/hero and that this iconography is borrowed from Greek art. ${ }^{36}$

Depictions of what has been termed the "Heros Equitans" are very similar to depictions of the rider on such gems. The imagery of the "Heros Equitans" presented a mounted warrior, frequently holding a spear. During their lives these heroes were perceived as the best and first of mortals and were characterized by physical strength, courage and an aweinspiring appearance. Such heroes often defended a particular area, where they were admired. Upon death, the heroes were worshiped and their burial place became sacred. "Heros Equitans" is often identified on votive reliefs with various divinities (e.g. Apollo, Asclepius, Dionysus, the Dioscuri). Perhaps the figure of "Heros Equitans", which was very

\footnotetext{
${ }^{28}$ Brandt 1972: no. 1671.

${ }^{29}$ Middleton 1991: App. 12a+b.

${ }^{30}$ Zwierlein-Diehl 1970: fig. 538.

${ }^{31}$ Middleton 1991: App. 12a+b.

32 Maaskant-Kleibrink 1978: 302, 305, no. 890.

${ }^{33}$ Henig 1997: no. 11.

${ }^{34}$ Spier 1992: no. 362.

${ }^{35}$ Henig 1973: 180, pl. 2.

${ }^{36}$ Dimitrova 2002: 209.
} 
common in the Greek east, ${ }^{37}$ is that which inspired the depictions of emperors and horsemen on gems. ${ }^{38}$

The "Heros Equitans" is extensively associated with the Underworld and is therefore a chthonic figure: stelae bearing his depiction have been found on graves and gravemounds; ${ }^{39}$ he is sometimes depicted in the company of an heroized dead figure ${ }^{40}$ and very frequently shown in connection with serpents, whose chthonic associations are well known. ${ }^{41}$ These rider-hero depictions were particularly common in Thrace, where one can find reliefs with their images on gravestones and votive plaques, also from the Roman imperial period, like that in the National Archaeological Museum, Sofia, which dates to the $2^{\text {nd }}$ century CE. ${ }^{42}$ Further, on a great many reliefs the "Thracian Horseman" is shown as a hunter. Such images of the "Thracian Horseman" as a hunter are often accompanied by representations of wild animals (boars, hares, deer, etc.) near altars, no doubt as a sign that they are about to be sacrificed. Thracian rider reliefs function as dedicatory, in view of the Thracian belief in the immortalization of the dead. ${ }^{43}$ Oppermann sees the "Thracian Horseman" as an indigenous protective divinity, ${ }^{44}$ whereas Boteva contends that, rather, the snake was thought of as divine, while the horseman was simply an envoy, a mediator between mortals and immortals. ${ }^{45}$

As previously discussed, the rider was apparently perceived by this gem's engraver and owner as some god or hero. ${ }^{46}$ However, since no altar, snake, or special gesture features on this Israel Museum gem, the identification of its rider with a "Heros Equitans" is equivocal and it is probably a Roman military rider or the rider-hunter with his prey.

The fifth and last gem is a carnelian intaglio $(12 \times 11 \mathrm{~mm})$ set in an original gold Roman ring. ${ }^{47}$ It depicts a naked horseman with long spiky hair, holding a long shield, here truncated at both ends, and of a type associated with the Gauls (Fig. 5). Part of the H. Stern Collection, it has not been published prior to this study. There are quite a number of Celtic/Gaulish horsemen featuring on gems. ${ }^{48}$ The horse seems to be stumbling, as though an extract from a celtomachy. Its origin may lie in the defeat of the Gauls at Pergamum in Hellenistic times. It is probable that people wore such gems as a reminder of the iconic defeat of the northern barbarians by the Attalids, as well as more recent Roman victories (over the Teutons and the Cimbri by Marius in 102-101 BCE and over several Gallic tribes in 50 BCE by Caesar in the Gallic Wars). In addition, the style and the engraving technique

\footnotetext{
${ }^{37}$ The majority of such reliefs come from the Black Sea region, Thrace, and Asia Minor.

${ }^{38}$ Cermanović-Kuzmanović 1992: 1019-1081.

${ }^{39}$ Kazarow 1918: 1133, 1140.

${ }^{40}$ Cermanović-Kuzmanović 1992: 56-60, 388-395, 565-570, 603, 638-639.

${ }^{41}$ Cermanović-Kuzmanović 1992: nos. 104-108, 113-126, 145, 148-154, 166-185, 204-213, 240-249. For further discussion see: Liapis 2011: 102-103.

42 Dimitrova 2002: 212, fig 1.

43 Dimitrova 2002: 227.

${ }^{44}$ Oppermann 2006: 276.

45 Boteva 2011: 101.

${ }^{46}$ Relating to the second carnelian gem from the Israel Museum (Fig. 2), IMJ 70.62.372.

${ }^{47}$ IMJ 76.42.2431.

${ }^{48}$ Zazoff 1975: no. 388 and the battle scene in no. 390; Maaskant-Kleibrink 1978: no. 402; Henig and Whiting 1987: no. 286; Henig and MacGregor 2004: nos. 7.26, 7.27 and 7.29 though these are helmeted.
} 
of this intaglio from the Israel Museum is compatible with the styles of the end of the Republican period, as defined by Maaskant-Kleibrink; hence, a dating of the first half of the $1^{\text {st }}$ century BCE is probable. ${ }^{49}$

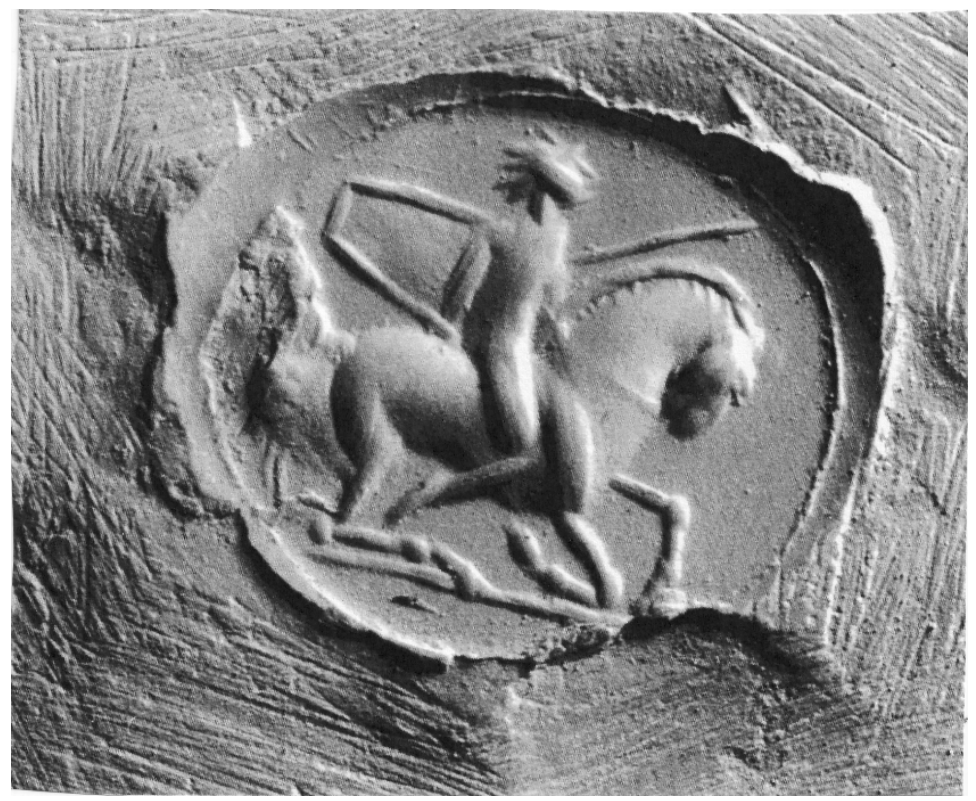

Fig. 5 - Gaulish horseman, Carnelian, 12 x 11 mm, c. 100-50 BCE, Israel Museum, inv. no. 76.42.2431.

In summary, horsemen frequently appear as images on intaglios. The Roman engraved gems drew their inspiration from established Greek rider imagery. Under the Roman Empire, the rider image became the preserve of that new divine figure, the Emperor. The imperial rider combined the attributes of a Bellerophon or the Dioscuri of the Classical period with those of an Alexander of the Hellenistic period. Figures of Gauls, too, are fairly common in art and there are quite a number of Celtic/Gaulish horsemen on gems. Presumably, people wore such gems as a reminder of the iconic defeat of the northern barbarians by the Attalids as well as more recent Roman triumphs. In addition, there are several examples of gems featuring a rider with a lion or other animal trampled beneath his horse's hooves. It is likely that such rider was perceived by the gem engraver and owner as a god or hero. Since these depictions of cavalrymen on gems are similar to the "Heros Equitans" image, they were possibly inspired by it, as were the depictions of the emperors.

We may say that cavalry engraved on gems were most probably selected by their owners as a marker of personal identity. The reasons that may have led an individual to choose a specific image as their symbol are no longer known to us. However, we can assume

\footnotetext{
${ }^{49}$ Maaskant-Kleibrink 1978: 179-180. The "Flat Bouterolle Style", one of the styles at end of the Roman Republic, is characterized by an exaggeration in the use of the large blunted drill for engraving the larger shapes such as bodies and heads. The limited detailing is done with rounded wheel grooves.
} 
that affluent, albeit ordinary people wished to resemble the ruling class as well as heroes through the purchase and use of these gems which also bear additional meanings of bravery and immortality.

\section{Acknowledgments}

Special thanks are due to Dr. Talila Michaeli, for her guidance throughout the research and invaluable help throughout the years. I would like to express my deep gratitude to Dr. Silvia Rozenberg for allowing me to publish the intaglios in the Israel Museum and for providing their photographs. I am indebted to Professor Martin Henig for advice and helpful comments on particular points. I wish to thank Naomi Paz for editing the English text.

\section{REFERENCES:}

Adams, N. 'The Garnet Millennium: The Role of Seal Stones in Garnet Studies', in: N. Adams and C. Entwistle (eds.), Gems of Heaven: Recent Research on Engraved Gemstones in Late Antiquity, London: British Museum, 2011, 10-24.

Anderson, J. K. Ancient Greek Horsemanship, Berkeley: University of California Press, 1961.

Boteva D. 'The “Thracian Horseman” reconsidered', in: I. P. Haynes (ed.), Early Roman Thrace, New Evidence from Bulgaria, Rhode Island: Journal of Roman Archaeology, Journal of Roman Archaeology Supplementary Series 82, 2011, 84-105.

Brandt, E. Antike Gemmen in deutschen Sammlungen, Bd. I: Staatliche Münzsammlung München, München: Prestel, 1972.

Cermanović-Kuzmanović, A. 'Heros Equitans', Lexicon Iconographicum Mythologiae Classicae VI, Zürich: Artemis \& Winkler Verlag, 1992, 1019-1081.

Dimitrova, N. 'Inscriptions and iconography in the monuments of the Thracian Rider', Hesperia, 71, 2002, 209-229.

Gliozzo, E., Mattingly, D. J., Cole, F. and Artioli, G., 'In the footsteps of Pliny: tracing the sources of Garamantian carnelian from Fazzan, south-west Libya', Journal of Archaeological Science, 52, 2014, 218-241.

Hamburger, A. ‘Gems from Caesarea Maritima’, ‘Atiqot, 8, 1968, 1-31

Hannestad, N. Roman Art and Imperial Policy, Aarhus: Aarhus University Press, 1986.

Harris, H. A. Sport in Greece and Rome, Ithaca, N.Y.: Cornell University Press, 1972.

Henig, M. 'A Cornelian Intaglio from Aldborough', The Yorkshire Archaeological Journal, 45, 1973, 180.

. 'Artistic patronage and the Roman military community in Britain', in: A. Goldsworthy and

I. Haynes (eds.), The Roman Army as a Community, Journal of Roman Archaeology supp. ser. 34 (1999), 150-164.

. 'The Meaning of Animal Images on Greek and Roman Gems', in: M. Avisseau Broustet (ed.) La glyptique des mondes classiques - mélanges en hommage à Marie-Louise Vollenweider, Paris: Bibliothèque National de France, 1997, 45-53.

Henig, M. and MacGregor, A. Catalogue of the Engraved Gems and Finger-rings in the Ashmolean Museum, vol. 2: Roman, Oxford: Archaeopress, 2004.

Henig, M. and Whiting, M. Engraved Gems from Gadara in Jordan: The Sa'd Collection of Intaglios and Cameos, Oxford: Oxford University Committee for Archaeology, 1987.

Houser, C. 'Alexander's influence on Greek Sculpture as seen in a Portrait in Athens', in: B. Barr- 
Sharrar and E. N. Borza (eds.), Macedonia and Greece in Late Classical and Early Hellenistic Times, Washington: National Gallery of Art, 1982, 228-238.

Johns, C. Horses: History, Myth, Art, Cambridge, MA: Harvard University Press, 2006.

Kazarow, G. 1918, 'Heros (thrakischer)', in: Realencyclopädie der classischen Altertumswissenschaft Suppl. III, Stuttgart : J.B. Metzlersche Buchhandlung, 1918, 1132-1148

Kurtz, D. and Boardman, J. Greek Burial Customs, London: Thames and Hudson, 1971.

Liapis, V. 'The Thracian Cult of Rhesus and the "Heros Equitans”', Kernos, 24, 2011, 95-104.

Maaskant-Kleibrink, M. Catalogue of the Engraved Gems in the Royal Coin Cabinet, The Hague: The Greek, Etruscan and Roman Collections, Hague: Govt. Pub. Office, 1978.

Mackintosh, M. The Divine Rider in the Art of the Western Roman Empire, Oxford: Tempus Reparatum, 1995.

Mattingly, D. J. (ed.), The Archaeology of Fazzan. Synthesis, vol. 1, London: Society for Libyan Studies, Department of Antiqities, 2003.

. (ed.), The Archaeology of Fazzan. Excavations carried out by C.M. Daniels, vol. 3, London: Society for Libyan Studies, Department of Antiqities, 2010.

. (ed.), The Archaeology of Fazzan. Survey and Excavations at Old Jarma (Ancient Garama) carried out by C.M. Daniels (1962-69) and the Fazzan Project (1997-2001), vol. 4, London: Society for Libyan Studies, Department of Antiqities, 2013.

Middleton, S. E. H. Engraved gems from Dalmatia, Oxford: Oxford University Committee for Archaeology, Institute of Archaeology, 1991.

Oppermann, M. Der thrakischen Reitter des Ostbalkanraumes im soannungsfeld von Grecitas, Romanitas und Lokalen Traditionen, Langenweisßach: Beier \& Beran, 2006.

Pannuti, U. Catalogo della Collezione Glittica, Roma: Museo Archeologico Nazionale di Napoli, 1983.

Platt, V. 'Making an Impression: Replication and the Ontology of the Graeco-Roman Seal Stone', Art History, 29 (2), 2006, 233-257.

Richter, G. M. A. Animals in Greek Sculpture, New York: Metropolitan Museum of Art, 1930.

Sena Chiesa, G. Gemme del Museo Nazionale di Aquileia, Aquileia: Associazione nazionale per Aquileia, 1966.

Snodgrass, A. M. Arms and Armour of the Greeks, Ithaca, N.Y.: Cornell University Press, 1967.

Spier, J. Ancient Gems and Finger Rings, Malibu, California: J. Paul Getty Museum, 1992.

Walters, H. B. Catalogue of the Engraved Gems and Cameos: Greek, Etruscan and Roman: in the British Museum, London: The Trustees of the British Museum, 1926.

Waurick, G. 'Helme der Hellenistischen Zeit und ihre Vorläufer', in: W-D. Heilmeyer (ed.), Antike Helme: Sammlung Lipperheide und andere Bestände des Antikenmuseums Berlin, Mainz: Roemisch-Germanischen Zentralmuseum, 1988, 159-163.

Woysch-Meautis, D. La representation des animaux et des êtres fabuleux sur les monuments funéraires grecs de l'époque archaïques à la fin du IV siècle av. J.C., Lausanne: Bibliothèque historique vaudoise, 1982.

Zanker, P. The Power of Images in The Age of Augustus, Ann Arbor: Univ. of Michigan Press, 1988.

Zazoff, P. Antike Gemmen in Deutschen Sammlungen, Bd. IV, Hannover, Kestner-Museum; Hamburg, Museum für Kunst und Gewerbe, Wiesbaden: F. Steiner, 1975. . Die antiken Gemmen, München: C. H. Beck, 1983.

Zwierlein-Diehl, E. Antike Gemmen in deutschen Sammlungen, Bd. II: Staatliche Museen Preußischer Kulturbesitz Antikenabteilung, Berlin, München: Prestel, 1969.

. Die antiken Gemmen des Kunsthistorischen Museums in Wien, Bd. I, München: Prestel Verlag, 1973. 


\section{IDIT SAGIV \\ Univerzitet u Tel-Avivu, Odsek za istoriju umetnosti \\ PREDSTAVA KONJANIKA NA GRČKO-RIMSKIM GEMAMA IZ MUZEJA IZRAELA U JERUSALIMU}

\section{Rezime}

Konjanik je bio jedna od najčešćih slika na rimskoj carskoj ikonografiji. Figure konjanika se pojavljuju kao pune skulpture ili skulpture na reljefima, kao slike ili u drugim vrstama umetnosti, između ostalog na gemama. U doba kad su napravljene, slike na gemama su imale značenje i često su bile simbolične. Glavna funkcija gema bila je da se otiskivanjem stvori predstava u reljefu na glini ili vosku koja bi mogla da se identifikuje i čija je uloga bila da se potvrdi nečiji potpis. Geme su bile veoma cenjene u antičko doba uopšte, a naročito u grčko-rimskom svetu.

Pet gema iz kolekcije klasične arheologije u Muzeju Izraela u Jerusalimu prikazuju konjanike na konjima u galopu kako drže koplja u ruci. U najvećem broju slučajeva ovi jahači su prikazani kako galopiraju tokom bitke. Motiv jahača koji prikazuje mitološke herojske jahače kao što su Belerofont verovatno je služio tome da oda počast jahačima palim u bitkama, a takođe je simbolizovao njihovo junaštvo i hrabrost.

Pored toga, postoji i nekoliko primeraka dragulja na kojima je jahač ispod čijeg konja se nalazi zarobljenik koji kleči ili leži. U drugim slučajevima slika konja ukazuje na to da lovac odlazi. Ove slike su bile uobičajene na rimskim sarkofazima, ali i na gemama. Neki naučnici pretpostavljaju da su graveri ili vlasnici gema jahača doživljavali kao boga ili heroja.

Prikazivanje onoga što se u istraživanjima zove „Heros Equitans“ veoma je slično prikazivanju jahača na gemama. Ovaj jahač predstavlja herojsku pojavu bez posebnog imena, a obično se prikazuje kako jaše konja. Za života ove heroje je karakterisala fizička snaga i hrabrost. Nakon smrti su obožavani a njihovi grobovi su postali sveti. „Heros Equitans“ se često identifikuju kao spomenici sa figurama različitih božanstava. Možda je figura „Heros Equitans“, koja je bila veoma česta u Grčkoj i okolnim prostorima, služila kao inspiracija za prikazivanje imperatora $i$ jahača na draguljima.

Rimske geme koje su na sebi imale sliku jahača inspirisane su ustanovljenim grčkim prikazivanjem jahača. Pod Rimskim carstvom slika jahača je postala način da se prikaže nova božanska figura - carska. Carski jahač je bio kombinacija osobina Belerofonta ili Dioskura iz klasičnog perioda, ili Aleksandra iz helenskog perioda.

Sem toga, Gali su bili prilično česti u umetnosti i postoji određeni broj keltskih/galskih konjanika na gemama. Pretpostavlja se da su ih ljudi nosili kao podsetnik na veliki poraz severnih varvara od Atalida ili na kasnije rimske pobede.

Stoga se može zaključiti da su konjanike koji su gravirani na gemama uglavnom birali vlasnici kao znak ličnog identiteta. Razlozi kojima su se rukovodili pojedinci u biranju određene slike kao sopstvenog simbola nama više nisu poznati. Ipak, možemo da pretpostavimo da su bogati, a obični ljudi želeli da liče na vladajuću klasu kao i na heroje, te su kupovali geme i koristili ih kao dodatni simbol hrabrosti i besmrtnosti.

Ključne reči: Geme, intaglio/tisak, konjanik, konjica, Heros Equitans, Belerofont, Dioskuri, carski jahač. 